\title{
Zinc in Soil Environment for Plant Health and Management Strategy
}

\author{
Harikamal Barman ${ }^{1, *}$, S. K. Das ${ }^{2}$, Aniruddha Roy ${ }^{3}$ \\ ${ }^{1}$ University of North Bengal, Department of Botany, India \\ ${ }^{2}$ ICAR RC for NEH Region, Soil Science Section, India \\ ${ }^{3}$ ICAR RC for NEH Region, Social Science Section, India
}

Copyright $\bigcirc 2018$ by authors, all rights reserved. Authors agree that this article remains permanently open access under the terms of the Creative Commons Attribution License 4.0 International License

\begin{abstract}
Zinc is an essential element for photosynthesis and its deficiency may play a role in the reduction of activity of rubisco and hence decreased rate of photosynthesis in higher plants. Zinc deficiency sometimes resembles $\mathrm{Fe} / \mathrm{Mn}$ deficiencies. Under severe zinc deficiency the shoot apices die ('die-back') as is widely distributed. Zinc toxicity leads to chlorosis in young leaves. Induced manganese deficiency might also be of importance as high zinc supply strongly decreases the manganese content of plants. Most preventing measures for zinc deficiency are selection of $\mathrm{Zn}$ efficient variety that is tolerant to high level of bicarbonate as well as low zinc in soil. Curative measure for correcting are application of $20-25 \mathrm{~kg} / \mathrm{ha} \mathrm{ZnSo} 4$ in acid soil, $22 \mathrm{~kg} \mathrm{Zn} / \mathrm{ha}$ initially followed by $5-10 \mathrm{~kg} \mathrm{Zn}$ in the later years or $50 \%$ gypsum $+10 \mathrm{t} \mathrm{GM}+22 \mathrm{~kg} \mathrm{Zn}$ once in 2-3 years in sodic soils, $1.0-1.5 \mathrm{~kg} / \mathrm{ha} \mathrm{Zn}$ as foliar spray at tillering stage and 2 times latter is very helpful for correct this deficiency. Zinc is very tightly bound to phytic acid and the formation of protein-zinc-phytic acid complexes increases the resistance to hydrolysis that leads to decrease in bioavailability of $\mathrm{Zn}$ to human and animals. Enrichment of cereal grains with $\mathrm{Zn}$ through both genetic (e.g., breeding) and agronomic (e.g., application of $\mathrm{Zn}$ fertilizers) biofortification is a high priority area of research, and will contribute to minimizing Zn-deficiency-related health problems in human populations.
\end{abstract}

Keywords Zinc, Deficiency, Toxicity, Chlorosis, Bicarbonate, Bioavailability

\section{Introduction}

Due to increase availability of $\mathrm{Ca}, \mathrm{Mg}, \mathrm{Cu}, \mathrm{Fe}, \mathrm{Mn}$ and $\mathrm{P}$ under prolonged submergence $\mathrm{Zn}$ availability and uptake hampered by the crops.Zinc is an important plant micronutrient for crop growth and higher production. Zinc
(Zn) deficiency is the most widespread micronutrient disorder in rice (often combined with $\mathrm{P}$ deficiency), but efforts to develop cultivars with improved tolerance have been hampered by insufficient understanding of genetic factors contributing to tolerance [1]. Zinc is essential for several biochemical processes such as cytochrome and nucleotide synthesis, enzyme activation, chlorophyll production, maintenance of membrane activity, increase rate of seed and stalk maturation. Nearly $50 \%$ of the cereal-grown areas in the world have soils with low plant availability of $\mathrm{Zn}$ to support either high crop yields or provide grains of high nutritional quality [2]. The regions with $\mathrm{Zn}$-deficient soils are also the regions where $\mathrm{Zn}$ deficiency in human beings is widespread. Zinc deficiency in soils and plants is a global micronutrient deficiency problem reported in many countries. Low solubility of $\mathrm{Zn}$ in soils rather than low total amount of $\mathrm{Zn}$ is the major reason for the widespread occurrence of $\mathrm{Zn}$ deficiency problem in crop plants. Zinc is an essential element for photosynthesis and its deficiency may play a role in the reduction of activity of rubisco and hence decreased rate of photosynthesis in higher plants [3]. There are a large number of enzymes in which $\mathrm{Zn}$ is an integral component. In these enzymes $\mathrm{Zn}$ has three functions: catalytic, cocatalytic, or structural. Enrichment of cereal grains with $\mathrm{Zn}$ through both genetic (e.g., breeding) and agronomic (e.g., application of $\mathrm{Zn}$ fertilizers) biofortification is, therefore, a high priority area of research, and will contribute to minimizing Zn-deficiency-related health problems in human populations.

\section{Zinc in Plant Enzyme}

In enzymes zinc has three functions; catalytic, cocatalytic (coactive), or structural. In enzymes with catalytic zinc functions (e.g., carbonic anhydrase and carboxypeptidase) the zinc atom is coordinated to four ligands, there of which are amino acids, with histidine (His) being the most frequent, followed by glutamine (Glu) and 
asparagine (Asp); a water molecule is the fourth ligand at all catalytical sites [4].In enzymes with structural zinc functions (e.g., alcohol dehydrogenase, and the proteins involved in DNA replication and gene expression) the structural zinc atoms are coordinated to the S-groups of four cysteine residues forming a tertiary structure of high stability [5]. Most of the zinc-enzymes have only one zinc atom per molecule, the alcohol dehydrogenase being an exception.

\subsection{Protein Synthesis}

The zinc content of ribosomal RNA in zinc-sufficient cells of Euglena is in the range 650-1280 $\mathrm{g} \mathrm{g} \mathrm{g}^{-1}$ RNA, whereas that in zinc deficient cells is $300-380 \mu \mathrm{g} \mathrm{g}^{-1}$ RNA. A clear inverse relationship exists between zinc supply and RNase activity and also between RNase activity and protein content. In the absence of zinc, ribosome disintegrates, but reconstitution takes place after resumption of zinc supply [6]. Zinc is a structural component of the ribosomes and essential for their structural integrity. Low protein contents and high amino acid contents in zinc-deficient plants are not only the result of reduced transcription and translation but also of enhanced rates of RNA degradation [7]. Higher rates of RNase activity are a typical feature of zinc deficiency. In shoot meristems of rice, disintegration of the $80 \mathrm{~s}$ ribosomes (soluble fraction in the cytoplasm) takes place when the zinc content drops below $100 \mu \mathrm{g} \mathrm{g}^{-1}$ dry weight [8]. In contrast to this rather high zinc content required for ribosome integrity, protein content starts to decrease at considerably lower zinc content.

\subsection{Carbonic Anhydrase}

This enzyme contains a single zinc atom which catalyzes the hydration of $\mathrm{CO}^{2}$.

$$
\mathrm{CO}_{2}+\mathrm{H}_{2} \mathrm{O} \rightleftarrows \mathrm{HCO}_{3}^{-}+\mathrm{H}^{+}
$$

Carbonic anhydrase (CA) from dicotyledons consists of six subunits and has a molecular weight of $180 \mathrm{k} \mathrm{Da}$, and six zinc atoms per molecule. The enzyme is localized both in the chloroplast and in the cytoplasm.

\subsection{Alcohol Dehydrogenase}

In zinc-deficient plants, alcohol dehydrogenase activity decreases, but the consequences for plant metabolism are not known. The situation is different in plants grown in waterlogged or submerged soils. This enzyme contains two zinc atoms per molecules, one with catalytic and the other with structural functions [9]. The enzyme catalyzes the reduction of acetaldehyde to ethanol. In higher plants under aerobic conditions, ethanol formation takes place mainly in meristematic tissues, such as root apices. In lowland rice flooding stimulates the activity of root alcohol dehydrogenase twice as much in zinc-sufficient compared with zinc-deficient plants, and the lower activity of this key enzyme in anaerobic metabolism might impair root functions of submerged rice considerably [10].

\subsection{CuZn-superoxide Dismutase}

In this enzyme zinc is associated with copper $(\mathrm{CuZn}$ SOD). Most likely the copper atoms represent the catalytic metal component and zinc the structural. With zinc deficiency SOD activity is much lower but can be restored in vitro by resupplying zinc to the assay medium, indicating that the zinc atom is an essential structural component for the normal functioning of CuZn SOD [11]. $\mathrm{Zn}$-deficiency caused the increase in $\mathrm{O}_{2} \cdot$ - production and higher contents of MDA in leaves. The SOD activity showed a decrease in $\mathrm{Zn} 0$ leaves, indicating that lowered capacity to scavenge the free radicals may be related to the over-accumulation of reactive oxygen species (ROS), which enhanced the rate of membrane peroxidation, i.e. MDA content in $\mathrm{Zn} 0$ leaves [12].

\section{Zinc on Photosynthesis}

Zinc deficiency depresses plant leaf's photosynthetic capacity. In cauliflower, reduction in photosynthesis induced by $\mathrm{Zn}$ deficiency is associated with a decrease in intercellular $\mathrm{CO}_{2}$ concentration and stomatal conductance [13]. The accumulation of saccharides can be observed in $\mathrm{Zn}$ deficient plants, especially in phloem sap source leaves, possibly resulting from either impaired phloem export of saccharides or decrease of sink demand. Reported a significant role of $\mathrm{Zn}$ in the regulation of the stomatal aperture is accounted for possible role of $\mathrm{Zn}$ in maintaining a high $\mathrm{K}$ content in guard cells [14]. A decrease in carbonic anhydrase activity due to $\mathrm{Zn}$ deficiency may also contribute to the reduced net photosynthetic rate, $P \mathrm{~N}$. A higher $P \mathrm{~N}$ in $\mathrm{Zn}$-deficiency resistant wheat cultivars than in a sensitive cultivar was related to higher carbonic anhydrase activity, because irrespective of Zn supply the resistant cultivar had an inherently higher carbonic anhydrase activity than the sensitive cultivar [15]. Additionally, the accumulation of saccharides in leaves may be related to decreases in photosynthetic $\mathrm{CO}_{2}$ fixation under low Zn. Zn-deficiency strongly reduced the photosynthetic performance in maize leaves: Net photosynthetic rate $(P \mathrm{~N})$, transpiration rate $(E)$, and stomatal conductance $(g \mathrm{~s})$ were decreased by 80,62 , and $69 \%$, respectively, in comparison to $\mathrm{Zn}_{5}$ (Zinc @ $5.0 \mathrm{mg}$ $\mathrm{kg}^{-1}$ soil). The water use efficiency, as assessed by $P \mathrm{~N} / E$, was enhanced markedly by $\mathrm{Zn}$ application [16].

\section{Zinc Deficiency on Carboxylating Enzymes (CE) and Carbonic Anhydrase (CA)}

Carbonic anhydrases is a ubiquitous enzyme among 
living organisms which catalyses the reversible interconversion of $\mathrm{CO}_{2}$ and $\mathrm{HCO}_{3}{ }^{-}$. Zinc has a catalytic role in plant and animal CA, being coordinated to the imidazole rings of three histidines close to the active site [17]. Since $\mathrm{CA}$ activity is affected by $\mathrm{Zn}$ deficiency and it also plays a very vital role in maintaining the inorganic carbon levels, this enzyme is used as a biochemical marker to diagnose $\mathrm{Zn}$ deficiency. RuBPC is the main carboxylating enzyme in $\mathrm{C}_{3}$ plants [18]. It may account for $50 \%$ or more of the total soluble leaf protein, making it the most common protein in nature. The activity of the enzyme decreased in leaves of maize and chick pea plants grown without $\mathrm{Zn}$ [19]. The decrease in RuBPC activity was almost $22 \%$ of the control values in maize plants, and about $34 \%$ for the chickpea plants. In $\mathrm{C}_{4}$ plants the initial carboxylation reaction occurs by PEPC. In higher plants, CA represents 1 to $2 \%$ of total soluble protein. The majority of CA activity in leaves of $\mathrm{C}_{3}$ plants resides within the stroma of the chloroplasts, thus showing a similar distribution pattern as RuBPC. Experimental evidence showed that $\mathrm{Zn}$ is tightly bound to the enzyme and it is essential for its activity [20]. It has been reported that CA activity is affected by $\mathrm{Zn}$ deficiency and $\mathrm{Zn}$ is an important regulator of the enzyme activity.

\section{Plant Growth and Zinc Interaction}

In plants as in other biological systems, zinc exists only as $\mathrm{Zn}(\mathrm{II})$, and does not take part in oxidoreduction reactions. The metabolic functions of zinc are based on its strong tendency to form tetrahedral complexes with N-, O-, and particularly S-ligands and it thereby plays both a functional (catalytic) and structural role in enzyme reactions [21]. In the last decade the role of zinc in protein molecules involved in DNA replication and in the regulation of gene expression has attracted much interest. Changes in metabolism brought about by zinc deficiency are quite complex. Nevertheless, some of the changes are typical and can be rather well explained by the function of zinc in specific enzyme reactions or steps in particular metabolic pathways [22].

\section{Zinc in Soil Environment}

\subsection{Deficiency}

Zinc deficiencies mainly occur when soil $\mathrm{pH}$ is high, high organic matter in soil, calcareous soils with high bicarbonate content, intensively cropped soils. Symptoms are common on younger or middle aged leaves [23], brown to dusty brown spots on younger leaves in red soils, yellowing of leaves/ midrib bleaching. Symptoms are prolonged during early growth stages due to immobilization of zinc. Symptoms of zinc deficiency sometimes resemble $\mathrm{Fe} / \mathrm{Mn}$ deficiencies. Zinc deficiency has also been associated with high bicarbonate content, a $\mathrm{Mg}: \mathrm{Ca}$ ratio in soils $>1$, intensive cropping, use of high yielding cultivars, and irrigation with alkaline water [24]. The most characteristic visible symptoms of zinc deficiency in dicotyledons are stunted growth due to shortening of internodes ('rosetting') and a drastic decrease in leaf size ('little leaf'). Under severe zinc deficiency the shoot apices die ('die-back') as is widely distributed, for example, in forest plantations in South Australia. Quite often these symptoms are combined with chlorosis, which is either highly contrasting or diffusive ('mottle leaf'). These symptoms are usually more severe in high light intensities than in partial shade [25]. In cereals such as sorghum, chlorotic bands along the midrib and red, spotlike discoloration (caused by anthocyanins) on the leaves often occur. In leaves, the critical deficiency laves are below 15-20 $\mu \mathrm{g} \mathrm{Zn} \mathrm{g}^{-1}$ dry weight.

\subsection{Toxicity}

Zinc toxicity leads to chlorosis in young leaves. This may be an induced deficiency, for example, of magnesium or iron, because of the similar ion radius of $\mathrm{Zn}^{2+}$ and $\mathrm{Fe}^{2+}$ and $\mathrm{Zn}^{2+}$ and $\mathrm{Mg}^{2+}$. When the zinc supply is large, zinc toxicity can readily be induced in nontolerant plants, inhibition of root elongation being a very sensitive parameter. Induced manganese deficiency might also be of importance as high zinc supply strongly decreases the manganese content of plants [26]. In bean plants zinc toxicity inhibits photosynthesis at various steps and through different mechanisms. Depressed RuBP carboxylase activity is presumably caused by competition with magnesium and inhibited PS II activity by replacement of manganese in the thylakoid membranes [27]. The critical toxicity levels in leaves in leaves of crop plants are from as low as $100 \mu \mathrm{g} \mathrm{Zn} \mathrm{g}^{-1}$ dry weight to more than $300 \mu \mathrm{g} \mathrm{Zn} \mathrm{g}^{-1}$ dry weight, the latter value being more typical.

\subsection{Management Practices}

Most preventing measures for zinc deficiency are selection of $\mathrm{Zn}$ efficient variety that is tolerant to high level of bicarbonate as well as low zinc in soil [28]. Application of $\mathrm{ZnSo}_{4}$ in nursery beds, drain the field, seedling root dipping in $2-4 \% \mathrm{ZnO}$ suspension, mid-season correction by spraying $0.5 \% \mathrm{ZnSO}_{4}$ thrice at weekly intervals between 3-6 WAT etc. Curative measure for correcting are application of $20-25 \mathrm{~kg} / \mathrm{ha} \mathrm{ZnSo}_{4}$ in acid soil, $22 \mathrm{~kg} \mathrm{Zn} / \mathrm{ha}$ initially followed by $5-10 \mathrm{~kg} \mathrm{Zn}$ in the later years or $50 \%$ gypsum $+10 \mathrm{t} \mathrm{GM}+22 \mathrm{~kg} Z n$ once in 2-3 years in sodic soils, $1.0-1.5 \mathrm{~kg} / \mathrm{ha} \mathrm{Zn}$ as foliar spray at tillering stage and 2 times latter is very helpful for correct this deficiency [29]. Plant $\mathrm{Zn}$ uptake from low $\mathrm{Zn}$ soils can be increased by $\mathrm{Zn}$ mobilizing chemical rhizosphere processes. 


\section{Zinc Tolerance in Crop}

Fairly close positive correlations in tolerant genotypes occur between accumulation of organic acids such as malate and citrate, and accumulation of zinc, indicating that complexation of zinc with organic acids in the vacuoles is in many cases an important mechanism of zinc tolerance [30].Tolerance is achieved mainly through sequestering zinc in the vacuoles. Whereas in the nontolerant clone receiving an abundant supply of zinc there is a preferential accumulation of zinc in the cytoplasm, in the tolerant clone the zinc concentration in the cytoplasm remains low; instead, zinc is sequestered in the vacuoles.

\section{Strategies to Control Zinc Deficiency}

Nutrition improvement with food fortification and medical supplements achieved in the developed world were unfortunately not successfully transferred to many developing countries even today. Most widely traditional strategies are supplementation with pharmaceutical preparations, disease reduction, food fortification and dietary diversification through consumption of a broad variety of foods, preferably from home gardens and small livestock production $[29,30]$. Success of fortification programmes and of micronutrient distribution in form of tablets to the population living in remote areas, to certain cultural groups and to the poor in growing towns is not obvious. Therefore, those who mostly need micronutrient supplementation are not reached. None of the current intervention strategies have been very successful in reducing the prevalence of micronutrient deficiency in developing countries, where malnutrition is still a major health problem [30,31]. On the opposite, genetically improved food, by breeding or gene transfer, may be a powerful intervention strategy targeting the most vulnerable population. Genetically improved plants can reach the rural areas and represent a sustainable system, with very low recurrent costs. So, considering the limitations associated with the traditional interventions and the strength of the food bio-fortification techniques, recently the research efforts have shifted towards bio-fortification of micronutrients in the edible tissues of staple food crop [31].

\section{Bioavailability and Zinc Binding Forms}

In wheat seeds, similarly high zinc contents were found in protein bodies in the scutellum. In the protein bodies of maize germ the phytate is mainly a mixed K-Mg-salt [32]. In grains and seeds, most of the $\mathrm{Zn}$ and other mineral elements, are localized in so-called 'protein bodies' in the form of discrete particles, the globoid crystals [33]. These globoids consisting mainly of 'phytate' i.e., salts of phytic acid. However, relatively large portions of the micronutrients zinc, manganese and iron, but not copper, are also bound as phytate. Zinc is very tightly bound to phytic acid and the formation of protein-zinc-phytic acid complexes increases the resistance to hydrolysis that leads to decrease in bioavailability of $\mathrm{Zn}$ to human and animals [34]. If phytic acid: $\mathrm{Zn}$ ratio $>15$, bioavailability of $\mathrm{Zn}$ decreased.

\section{Zinc in Bio-Fortification}

The regions with $\mathrm{Zn}$-deficient soils are also the regions where $\mathrm{Zn}$ deficiency in human beings is widespread. There are several examples demonstrating that applying $\mathrm{Zn}$ fertilizers to cereal crops improve not only productivity, but also grain $\mathrm{Zn}$ concentration of plants $[33,34]$. Agronomic measures for micronutrients bio-fortification includes adequate fertilization, proper source, method and timing of fertilizer application, FYM application (INM), crop rotation, intercropping and all other agronomic practices that ensure proper availability of micronutrients in soil. Fertilizer strategy could be a rapid solution to the problem of micronutrient deficiency. Depending on the soil conditions and application form, $\mathrm{Zn}$ fertilizers can increase grain $\mathrm{Zn}$ concentration up to fourfold under field conditions $[35,36]$. Zinc has been sprayed on foliar in form of $\mathrm{ZnSO}_{4}$ at the rate of $0.5 \%(\mathrm{w} / \mathrm{v})$. Zinc applications have been realized at the following growth stages: (1) stem elongation and booting stages, (2) milk and dough stages, (3) booting and milk stages and (4) booting, milk and dough stages. Once the micronutrient content of the seed is improved by any bio-fortification technique, say agronomic bio-fortification, it has several agronomic advantages besides improving human nutrition [35,36,37]. Fertilizer studies focusing specifically on increasing $\mathrm{Zn}$ concentration of grain (or other edible parts) are, however, very rare, although a large number of studies are available on the role of soil and foliar applied $\mathrm{Zn}$ fertilizers in correction of $\mathrm{Zn}$ deficiency and increasing plant growth and yield. The highest increase in grain yield was obtained with soil, soil + foliar and seed + foliar applications. When a high concentration of grain $\mathrm{Zn}$ is aimed in addition to a high grain yield, combined soil and foliar application is recommended [37]. Alternatively, using seeds with high $\mathrm{Zn}$ concentrations at sowing together with foliar application of $\mathrm{Zn}$ is also an effective way to improve both grain yield and grain $\mathrm{Zn}$ concentration. Timing of foliar $\mathrm{Zn}$ application is an important factor determining the effectiveness of the foliarly applied $\mathrm{Zn}$ fertilizers in increasing grain $\mathrm{Zn}$ concentration. It is expected that large increases in loading of $\mathrm{Zn}$ into grain can be achieved when foliar $\mathrm{Zn}$ fertilizers are applied to plants at a late growth stage [38-39]. Ozturk et al. studied changes in grain 
concentration of $\mathrm{Zn}$ in wheat during the reproductive stage and found that the highest concentration of $\mathrm{Zn}$ in grain occurs during the milk stage of the grain development.

\section{Conclusions}

Zinc is an essential element for photosynthesis and its deficiency may play a role in the reduction of activity of Rubisco and hence rate of photosynthesis in higher plants. Zinc deficiency is responsible for many severe health complications, including impairments of physical growth, immune system and learning ability, combined with increased risk of infections, DNA damage and cancer development. Status of $\mathrm{Zn}$ deficiencies should be assessed and the results should be used for planning interventions aimed at improving the $\mathrm{Zn}$ status of the population. Enrichment of cereal grains with $\mathrm{Zn}$ through both genetic (e.g., breeding) and agronomic (e.g., application of $\mathrm{Zn}$ fertilizers) biofortification is a high priority area of research, and will contribute to minimizing Zn-deficiency-related health problems in human populations.

\section{REFERENCES}

[1] Salama, Z.A., El-Fouly, M.M.,Lazova, G. and Popova, L.P. (2006). Carboxylating enzymes and carbonic anhydrase functions were suppressed by zinc deficiency in maize and chick pea plants. Acta Physiologiae Plantarum, 28(5): 445-451.

[2] Coleman, J.E. (1992). Zinc proteins: enzymes, storage proteins, transcription factors, and replication proteins. Annu. Rev. Biochem., 61: 897-946.

[3] Fischer, E.S., Thimm, O. and Rengel, Z. (1997). Zinc nutrition influences the $\mathrm{CO} 2$ gas exchange in wheat. Photosynhetica, 33: 505-508.

[4] Rengel, Z. (1995). Carbonic anhydrase activity in leaves of wheat genotypes differing in zinc efficiency. - J. Plant Physiol., 147: 251-256.

[5] Graham, R.D., Welch, R.M. (1996). Breeding for staple-food crops with high micronutrient density: Working Papers on Agricultural Strategies for Micronutrients, No.3. International Food Policy Institute, Washington DC

[6] Das SK, Mukherjee I, Das SK. Dissipation of flubendiamide in/on Okra [Abelmoschus esculenta (L.) Moench] Fruits. Bulletin of Environmental Contamination and Toxicology, 2012;88;381-384

[7] Alloway, B.J. (2004). Zinc in soils and crop nutrition. IZA Publications. International Zinc Association, Brussels, pp $1-116$.

[8] Das SK, Mukherjee I, Kumar A. Effect of soil type and organic manure on adsorption-desorption of flubendiamide. Environmental Monitoring and Assessment, 2015;187:403.
DOI 10.1007/s10661-015-4623-2.

[9] Rengel, Z., Batten, G.D. and Crowley, D.E. (1999). Agronomic approaches for improving the micronutrient density in edible portions of field crops. Field Crops Res., 60: $27-40$.

[10] Cakmak, I., Kalayci, M., Ekiz, H., Braun, H.J. and Yilmaz, A. (1999). Zinc deficiency as an actual problem in plant and human nutrition in Turkey: A NATO-Science for Stability Project. Field Crops Res, 60: 175-188.

[11] Das SK, Mukherjee I. Effect of light and pH on persistence of flubendiamide. Bulletin of Environmental Contamination and Toxicology, 2011;87:292-296.

[12] Bouis, H.E. (2003). Micronutrient fortification of plants through plant breeding: can it improve nutrition in man at lowcost? Proc Nutr Soc., 62:403-411.

[13] Cakmak, I. (2008). Enrichment of cereal grains with zinc: agronomic or genetic biofortification? Plant Soil, 302: 1-17.

[14] Das SK and Mukherjee I. 2014. Influence of microbial community on degradation of flubendiamide in two Indian soils. Environmental Monitoring \& Assessment, 186: $3213-3219$

[15] Mortvedt, J.J. and Gilkes, R.J. (1993). Zinc fertilizers. In: Robson AD (ed) Zinc in soils and plants. Kluwer, Dordrecht, The Netherlands, pp. 33-44.

[16] Das SK, Mukherjee I. Flubendiamide transport through packed soil columns. Bulletin of Environmental Contamination and Toxicology, 2012;88:229-233.

[17] Boardman, R. and McGuire, D.O. (1990). The role of zinc in forestry. I. Zinc in forest environments, ecosystems and tree nutrition. Forest Ecol. Mgmt, 37: 167-205.

[18] Das S. K., \& Mukherjee I. (2012). Effect of moisture and organic manure on persistence of flubendiamide in soil. Bull Environ Contam Toxicol, 88, 515-520.

[19] Brookes, A., Collins, J.C. and Thurman, D.A. (1981). The mechanism of zinc tolerance in grasses. J. Plant Nutr., 3: 695-705.

[20] Yilmaz, A., Ekiz, H., Torun, B., Gultekin, I., Karanlik, S., Bagci, S.A. and Cakmak, I. (1997). Effect of different zinc application methods on grain yield and zinc concentration in wheat grown on zinc-deficient calcareous soils in Central Anatolia. J Plant Nutr., 20: 461-471.

[21] Das SK. 2013. Mode of action of pesticides and the novel trends-a critical review. International Research Journal of Agricultural Science and Soil Science. 3(11): 393-403.

[22] Solomons, N.W. and Cousins, R. (1984). Zinc. P. 125-197. In N. Solomons and I. Rosenberg (ed.) Absorption and malabsorption of mineral nutrients. Alan R. Liss, New York.

[23] Mukherjee I, Das SK, Kumar A. 2012. A Fast Method for Determination of Flubendiamide in Vegetables by Liquid Chromatography. Pesticide Research Journal 24 (2), 159-162

[24] Tsuzuki, M., Miyachi, S. and Ed wards, G.E. (1985). Localization of carbonic anhydrase in mesophyll cells of terrestrial $\mathrm{C} 3$ plants in relation to $\mathrm{CO} 2$ assimilation. Plant Cell Physiol., 26: 881-891. 
[25] Vallee, B.L. and Auld, D.S. (1990). Zinc coordination, function and structure of zinc enzymes and other proteins. Biochemistry, 29: 5647-5659.

[26] Ozturk, L., Yazici, M.A., Yucel, C., Torun, A., Cekic, C., Bagci, A., Ozkan, H., Braun, H.J., Sayers, Z. and Cakmak, I. (2006). Concentration and localization of zinc during seed development and germination in wheat. Physiol Plant, 128: 144-152.

[27] Das SK, Avasthe RK, Gopi R. 2014. Vermiwash: use in organic agriculture for improved crop production. Popular Kheti 2, 45-46.

[28] Roy A, Das SK, Tripathi AK, Singh NU. 2015. Biodiversity in North East India and their Conser vation. Progressive Agriculture 15 (2) : 182-189 (2015).

[29] Barman H, Roy A, Das SK. 2015. Evaluation of plant products and antagonistic microbes against grey blight (Pestalotiopsis theae), a devastating pathogen of tea. African Journal of Microbiology Research 9 (18), $1263-1267$.

[30] Vaughan, D., DeKock, P.C. and Ord, B.G. (1982). The nature and localization of superoxide dismutase in fronds of Lemma gibba L. and the effect of copper and zinc deficiency on its activity. Physiol. Plant., 54: 253-257.

[31] Alloway, B.J. (Ed.): (2001). Zinc - the vital micronutrient for healthy, high-value crops. - International Zinc Association, Brussels.
[32] Das SK, Avasthe RK. 2015. Carbon farming and credit for mitigating greenhouse gases Current Science 109 (7), 1223.

[33] Wang, H. and Jin, J.Y. (2005). Photosynthetic rate, chlorophyll fluorescence parameters, and lipid peroxidation of maize leaves as affected by zinc deficiency. Photosynthetica, 43(4): 591-596.

[34] Das SK. 2014. Chemicals responsible for systemic acquired resistance in plantsa critical review. J. Atoms and Molecules $4(3), 45-51$

[35] Das SK. 2014. Scope and Relevance of using Pesticide Mixtures in Crop Protection: A Critical Review. International Journal of Environmental Science and Toxicology 2 (5), 119-123.

[36] Das SK. 2014. Recent development and future of botanical pesticides in India. Popular Kheti 2 (2), 93-99.

[37] CJ Mate, I Mukherjee, SK Das. 2015. Persistence of spiromesifen in soil: influence of moisture, light, $\mathrm{pH}$ and organic amendment. Environmental monitoring and assessment 187, 7 .

[38] Das SK, Avasthe RK, Singh M, Sharma K. 2015. Biobeds: on-farm biopurification for environmental protection. Current Science 109 (9), 1521-1521.

[39] Das SK, Avasthe RK, Singh R and Babu S. 2014. Biochar as carbon negative in carbon credit under changing climate. Current Science 107 (7), 1090-1091. 